\title{
REORIENTASI PERANAN PESANTRENPADA ERA PEMBANGUNAN MENUJU PARTISIPASI PEMBERDAYAAN MASYARAKAT BAWAH
}

\author{
Taufik Nugroho \\ PAI-FAI-UCY \\ Taufiknugroho54@gmail.com
}

\begin{abstract}
It goes without saying that Pesantren has been a site of great potential to continue its role playing more broadly, not only as confine as to become a guardian of social piety and the center for the spreading of Islam in the countryside, but also playing its role as a counter part for the development of the Indonesian government. The expansion is on the aspect of political policies, empowerment of the people's economy as well as character education .
\end{abstract}

Keywords: Pesantren, development, empowerment, community

Abstrak: Pondok Pesantren memiliki potensi besar untuk terus memainkan perannya secara lebih luas, tidak hanya sebagai penjaga nilai kesalehan masyarakat dan pusat penyebaran Islam di pedesaan, tetapi juga memainkan peran sebagai counter part bagi pembangunan pemerintah Indonesia. Perluasan tersebut yaitu pada aspek sosial politik, pemberdayaan perekonomian rakyat serta pendidikan karakter.

Kata kunci: Pesantren, pembangunan, pemberdayaan, masyarakat

\section{A. Pendahuluan}

Lembaga pendidikan Islam di Indonesia yang dinilai asli adalah pesantren. Pelacakan historis dari Abdurrahman Wahid dalam Taufik telah menyimpulkan bahwa pesantren tidak hanya identik dengan keislaman, tetapi juga keaslian pendidikan Indonesia. ${ }^{1}$

Berapa jumlah pasti Pondok Pesantren di Indonesia? Kemenag pada tahun 2009 merilis jumlah Pondok pesantren di Indonesia sebanyak 21.521 dengan santri 3.318.469. ${ }^{2}$ Sampai dengan tahun 2016 belum ada informasi up-date data yang akurat tentang pondok pesantren di Indonesia. Selama ini, Pondok Pesantren dikenal menjadi tempat untuk pembinaan moral kesalehan santri dan pembelajaran ilmu-ilmu agama

${ }^{1}$ Taufik Nugroho, "Analisis Manajemen Pendidikan Terhadap Kualitas Madrasah Indonesia," Jurnal Ulumuddin 6, no. 2 (2016): 80-87.

2R. Lukman Fauroni, Model Bisnis Ala Pesantren (yogyakarta: Kaukaba, 2014), h. 2 
Islam serta pusat penyebaran Islam di pedesaan. ${ }^{3}$ Informasi penting pada era colonial, Pondok Pesantren dikenal sebagai basis persemaian sikap oposisi dan perlawanan terhadap penjajah Belanda. Sejumlah pemberontakan terhadap penjajah Belanda dimotori oleh Pondok Pesantren. Semua fakta di atas adalah catatan ringkas tentang prestasi pesantren dan sumbangannya kepada bangsa Indonesia. ${ }^{4}$

Bagaimana peran Pondok Pesantren Post Kemerdekaan ? Eksistensi Pondok Pesantren post Kemerdekaan di Indonesia, tetap diakui oleh bangsa Indonesia. Kehidupan Pondok Pesantren post kemerdekaan Indonesia merupakan kelanjutan kehidupan Pondok Pesantren era colonial. Pondok Pesantrenn masih terus memainkan perannya sebagai penjaga gawang pendidikan Islam di pedesaan; pembelajaran ilmu-ilmu agama Islam, pembinaan keshalehan para santri dan pusat penyebaran Islam serta dikenal pada sisi kesederhanaannya. ${ }^{5}$

Pada saat yang sama, sejak Kemerdekaan, bangsa Indonesia mengumandangkan pembangunan di seluruh aspek kehidupan. Programprogram pembangunan diberbagai periode sejak era Orde Lama Orde Baru sampai dengan era Reformasi terus bergerak maju. Dinamika pembangunan bangsa Indonesia yang berlangsung selama ini bukan tanpa kendala. Banyak prestasi yang mengesankan telah dicapai oleh bangsa Indonesia selama era pembangunan berlangsung. Tetapi juga banyak idealisme yang tertinggal; carut-marut kehidupan sosial politik, masih ada sebagian rakyat Indonesia tertinggal secara ekonomi, konflik etnis, ras. Ada pertanyaan besar yang harus di jawab pesantren, mengapa Pondok Pesantren yang jumlahnya ribuan dinilai banyak pihak belum menyumbang secara signifikan terhadap pembangunan?

Tidak mudah menjawab pertanyaan tersebut. Tetapi Pesantren memiliki potensi besar untuk terus memainkan perannya secara lebih

3 Zamakhsyari Dhofier, Tradisi Pesantren (Jakarta: LP3ES, 1994), h. 16

4Imroatun Imroatun, "Kontribusi Lembaga Pendidikan Agama Islam Dalam Penguatan Identitas Bangsa," Jurnal Ilmiah Bidang pendidikan Studia Didaktika 8, no. 1 (2016).

5 Umi Musaropah, "Pemberdayaan Masyarakat Dalam Penyelenggaraan Pendidikan Anak Usia Dini Berbasis Pesantren," aș-șibyan, Jurnal Pendidikan Guru Raudlatul Athfal, Vol.1, No.2, Tahun 2016, h. 177-185, http://jurnal.uinbanten.ac.id/ index.php/assibyan/ article/ view/203 
luas, tidak hanya sebagai penjaga nilai kesalehan masyarakat dan pusat penyebaran Islam di pedesaan, tetapi juga memainkan peran sebagai counter part bagi pembangunan pemerintah Indonesia. Dengan kata lain, Pondok Pesantren dapat mengambil bagian dalam agenda-agenda pembangunan. Diantara agenda tersebut yaitu: pemberdayaan perekonomian rakyat pedesaan, pendidikan perempuan serta pemberdayaan litarasi teknologi masyarakat. Menurut penulis, peranperan tersebut belum dilaksanakan secara luas dan massive. Sejumlah data mengatakan bahwa baru sebagian kecil Pondok Pesantren yang melakukan perluasan peran tersebut.

\section{B. Pesantren dan Pemberdayaan Masyarakat}

1. Watak Dasar Pesantren

Pesantren, sebagaimana kita ketahui, merupakan lembaga pendidikan tradisional yang lekat dengan tradisi Islam. Lembaga tersebut tumbuh dan berkembang di atas cita-cita Islam. 5 Dilihat dari sudut pandang sejarah, pondok pesantren merupakan lembaga pendidikan Islam yang tumbuh dan berkembang di tengah-tengah masyarakat Indonesia sejak zaman pra-kemerdekaan. ${ }^{6}$ Keberadaan pesantren terus tumbuh dan berkembang seirama dengan perkembangan zaman sampai sekarang.

Pesantren pada satu sisi adalah lembaga pendidikan non formal yang mengajarkan dan menyebarkan ajaran Islam di pedesaan. Sementara itu pada sisi yang lain, fakta sejarah menunjukkann bahwa pesantren dalam era colonial telah menjadi salah satu motor pergerakan perlawanan terhadap penjajah Belanda. Pada era post kolonial, pesantren telah ikut serta menyumbang di bidang sumberdaya manusia. Tak sedikit lulusan pesantren menjadi tokoh-tokoh nasional menduduki posisi-posisi penting dalam struktur kenegaraan diberbagai level dan unit kerja. Selain itu, banyak alumni pesantren yang memilih terjun di masyarakat mendirikan pesantren dan lembaga-lembaga swadaya masyarakat. Identitas

6Departemen Pendidikan dan Kebudayaan RI, Pendidikan di Indonesia Dari Jaman ke Jaman (Jakarta: Badan Penelitian dan Pengembangan Pendidikan dan Kebudayaan, 1979), h. 27 
pesantren - sebagai penyebar dan pusat pengajaran Islam dan perlawanan terhadap penjajahan, telah dikenal lama oleh masyarakat.

Pesantren sebagai tempat memperdalam agama Islam sekaligus sebagai tempat penyebaran agama Islam, diperkirakan berkembang seiring dengan proses pengislaman di tanah Jawa. ${ }^{7}$ Pesantren adalah salah satu lembaga yang tumbuh dan berkembang dalam masyarakat untuk melayani berbagai kebutuhan masyarakat. Artinya, sejak kelahirannya, pesantren tidak hanya, berfungsi mengajarkan dan menyebarkan agama Islam tetapi juga berfungsi di luar hal tersebut. Seorang kyai juga sebagai tempat bertanya tentang politik kenegaraan, pengembangan perekonomian pedesaan dll. Seiring dengan perkembangan zaman, fungsi-fungsi tersebut tidak hilang, bahkan mengembang dan meluas, khusunya dalam bidang bisnis. ${ }^{8}$ Dengan demikian, dapat disimpulkan bahwa pesantren telah menjadi satu kesatuan integral yang tidak dapat lepas dari realitas obyektif masyarakat dan berupaya menjawab tantangan zaman.

2. Kemungkinan Perluasan Peran Pondok Pesantren

a. Mengubah persepsi

Selama ini, sebagian pengelola Pondok Pesantren dan masyarakat muslim di Indonesia memiliki pandangan bahwa pesantren adalah tempat mempelajari agama Islam, penjaga nilai-nilai kesalehan individu dan masyarakat. Pesantren bukan tempat melakukan kegiatan perekonomian, pengembangan agrobisnis. Persepsi inilah yang menjadi salah satu kendala peran Pondok Pesantren tak dapat keluar dari kerangka besi yang mengurungnya. Karena itu, persepsi tersebut perlu diubah menjadi Pondok Pesantren memiliki tugas-tugas sosial kemasyarakatan yang berupa; pengembangan unit usaha, pertanian, home industry dll.

b. Peran Sosial Politik

Affan Gaffar dalam Amir Mahmud mengatakan bahwa peran pesantren dalam masyarakat dapat dilakukan dalam tiga hal: 1.

7Amir Mahmud, "Pesantren dan Pergerakan Islam, Studi Tentang Alumni Pondok Pesantren al-Mukmin, Ngruki, Surakarta” (UIN Sunan Kalijaga, 2008), h. 145

8Fauroni, Model Bisnis Ala Pesantren, h. 45 
Mendukung dan memberdayakan masyarakat level grassroot, 2. Meningkatkan peran sosial politik secara luas, 3. Ikut serta dalam agenda pembangunan dalam sector pendidikan (Agent of rural development). ${ }^{9}$ Perlu di catata bahwa pelibatan pesantren dalam peran sosial politik menjadi sangat penting dalam era pembangunan. Dalam banyak hal, masyarakat pedesaan lebih percaya dan mendengarkan apa yang dikatakan kyai dari pada apa yang dikatakan pejabat.

Karena itu, peran sosial politik Pondok Pesantren seyogyanya terintegrasi dengan program-program pemerintah. Kesan kental Pondok Pesantren dengan karakter utama tradisi Islam sebagai poros sosial pengemban misi Islam diperluas dalam bentuk; membangun nasionalisme Indonesia, $^{10}$ mempersiapkan para santri untuk hidup berdampingan dengan agama lain di masyarakat, mengemas pesan-pesan pokok Islam dalam bahasa keadilan, demokrasi dan kemanusiaan.

Peran sosial politik Pondok Pesantren ibaratnya sebilah pisau bermata dua; yakni sebagai penyeimbang program pembanguan yang hegemonic dan sekaligus melakukan kritik argumentative terhadap program pembangunan sentralistik yang sedang berjalan. Ide demikian tentu berjalan dengan keyakinan bahwa penyimpangan dari Islam telah dieliminir.

Maka Isu agama baru seperti persesuaian dengan HAM sudah diantisipasi. Pesantren Bahkan bisa andil mensosialisasikannya terutama di bidang politik. Konsep pengakuan HAM dalam Islam yang anti diskriminatif dan tentunya berbicara jaminan hak politik bagi perempuan tentunya sama dengan laki-laki sehingga setara dalam pertisipasi di dunia politik. ${ }^{11}$

Ide perluasan peran ini hadir pada tahun 1970-an. Apa yang dilakukan oleh Pondok Pesantren Pabelan dengan motor utama Kyai

9Mahmud, "Pesantren dan Pergerakan Islam, Studi Tentang Alumni Pondok Pesantren al-Mukmin, Ngruki, Surakarta," h. 20

${ }_{10}$ Imroatun, "Kontribusi Lembaga Pendidikan Agama Islam Dalam Penguatan Identitas Bangsa.”

${ }_{11}$ Andrie Irawan, "Jaminan Hak Politik Perempuan Dalam Islam," Jurnal Ulumuddin 4, no. 2 (2014): 80-87. 
Hamam Dja'far sangat aktif merealisasikan ide-ide tersebut. ${ }^{12}$ Sehingga Pondok Pesantren Pabelan dinilai oleh banyak pihak sebagai pilot projek Pengambangan Pesanten di era Orde Baru berbasis masyarakat.

c. Peran Pemberdayaan Perekonomian Rakyat

Sejumlah informasi mengatakan bahwa program pembangunan pada era Orde Baru yang berlanjut pada era Reformasi, tidak semua lapisan masyarakat menikmati hasil pembanguan tersebut. Program pembangunan era Orde Baru yang menekankan pada pertumbuhan dengan karakter utama Top Down, disinyalir lebih banyak dinikmati oleh sebagian kecil warga Negara Indonesia. Sedangkan bagian besar bangsa Indonesia sering disebut sebagai penonton pembangunan di rumah sendiri. Sebagian besar warga yang kurang beruntung tersebut adalah ummat Islam yang grassroot.

Sesuatu yang sangat strategis, jika Pondok Pesantren yang berbasis di pedesaan mengambil peran ini. Walaupun peran pemberdayaan masyarakat sering dikatakan di luar fungsi utama Pondok Pesantren, tetapi peran tersebut memiliki nilai strategis. Nilai strategis tersebut terletak pada kemampuan Pondok Pesantren mengembangkan dan membahasakan dakwah Islam melalui kerja nyata atau dikenal dengan nama dakwah bil hal. Dengan kata lain, Pondok Pesantren dapat mengambil peran pemberdayaan perkononomian masyarakat melalui pendekatan Bottom Up.

d. Peran Penguatan Pendidikan karakter

Program pendidikan yang dicanangkan pemerintah, baik formal mapun non formal sudah sangat maju serta well organized didukung oleh pendanaaan raksasa. Namun demikian, tidak ada jaminan dengan organisi yang rapi didukung dana raksasa, program pendidikan akan mencapai keberhasilan. Banyak kalangan menilai bahwa program pendidikan pemerintah hanya berhasil pada aspek cognitive dan psikomotor. Sedangkan pada aspek afektif, program pendidikan masih dipertanyakan hasilnya.

${ }^{12}$ Fauroni, Model Bisnis Ala Pesantren, h. 3 
Sementara itu, Pondok Pesantren yang sering dinilai oleh beberapa kalangan, sebagai lembaga pendidikan ketinggalan zaman. ${ }^{13}$ tidak prospektif secara ekonomi dan tradisional dibidang keilmuan. Namun penilaian itu semua terbantahkan dengan prestasi Pondok Pesantren pada bidang karakter. Dengan segala kesederhanaan, fasilitas fisik atau sarana prasarana yang sangat menimal untuk mengatakan tak ada sema sekali, biaya mandiri tanpa dukungan berarti dari pemerintah, Pondok Pesantren berhasil membangun kepribadian para santri menjadi individu yang ikhlas, zuhud, rela berkorban. ${ }^{14}$

Isu tentang penurunan moralitas bangsa dengan indikator; korupsi merajalela secara terang-terangan diberbagai unit kerja pemerintah maupun parlemen, konflik ras, tawuran anak antar sekolah, kekerasan antar warga, kesemuanya itu mengindikasikan menurunnya moralitas bangsa.

Pesantren yang mengutamakan pemahaman Quran, sementara di dalamnya adalah salah satu sumber dalam perumusan teori maupun dalam pelaksanaan pendidikan karakter Islam. ${ }^{15}$ Sumber yang dimaksud bukanlah merupakan satu-satunya sumber, karena disamping Al-Qur'an, hadits Nabi dan Ijtihad yang dapat diterima dapat dijadikan sumber lain yang berfungsi sebagai penguat sekaligus pelengkap Al-Qur'an sebagai landasan pendidikan Islam

Pondok Pesantren dengan segala kualitasnya menjadi salah satu model pembelajaran karakter. Peran pada aspek inilah yang mungkin dapat dimainkan oleh pesantren sebagai counter part pemerintah dalam program pembangunan pendidikan. Azra telah menyimpulkan secara tepat posisi pendidikan dalam pesantren. Dalam dinamika keilmuan pesantren, terdapat tiga fungsi pokok pesantren : pertama transmisi ilmu pengetahuan Islam (transmision of Islamic knowledge); kedua,

13Karel A Steenbrink, Pesantren, Madrasah, Sekolah (Jakarta: LP3ES, 1986), h. 9.

14Departemen Agama RI, Dinamika Perkembangan Pondok Pesantren (Jakarta: Departemen Agama RI, 2005), h. 1

${ }_{15}$ Taufik Nugroho, "Pendidikan Karakter Dalam Al-Qur'an (Studi Tafsir Pendidikan Surat Luqman)," Jurnal Ulumuddin 4, no. 1 (2014): 14-22. 
pemelihara tradisi Islam (maintenance of Islamic tradition); dan ketiga, pembinaan calon-calon ulama (production of ulama). ${ }^{16}$

\section{Kesimpulan}

Pondok Pesantren secara umum telah menyumbangkan pretasi terbaiknya di era kolonial yakni sebagai tempat persemaian nasionalisme Indonesia dan basis perlawanan terhadap penjajah Belanda. Kemudian dilanjutkan pada era post kemerdekaan, Pondok Pesantren telah ikut serta memainkan peran utamanya bidang pendidikan. Peran subpendidikan tersebut terletak pada pembinaan kepribadian; keshalehan para santri dalam bentuk keikhlasan, tawadu', tanggung jawab, amanah dan taat pada ajaran pokok Islam lainnya. Namun demikian, pada era pembangunan, peran Pesantren perlu di perluas. Perluasan tersebut yaitu pada aspek sosial politik, pemberdayaan perekonomian rakyat serta pendidikan karakter.

\section{Daftar Pustaka}

Azra, Azyumardi. Esei-esei Intelektual Muslim dan Pendidikan Islam. Jakarta: logos Wacana Ilmu, 1998.

Departemen Agama RI. Dinamika Perkembangan Pondok Pesantren. Jakarta: Departemen Agama RI, 2005.

Departemen Pendidikan dan Kebudayaan RI. Pendidikan di Indonesia Dari Jaman ke Jaman. Jakarta: Badan Penelitian dan Pengembangan Pendidikan dan Kebudayaan, 1979.

Dhofier, Zamakhsyari. Tradisi Pesantren. Jakarta: LP3ES, 1994.

Fauroni, R. Lukman. Model Bisnis Ala Pesantren. yogyakarta: Kaukaba, 2014.

Imroatun, Imroatun. "Kontribusi Lembaga Pendidikan Agama Islam Dalam Penguatan Identitas Bangsa." Jurnal Ilmiah Bidang pendidikan Studia Didaktika 8, no. 1 (2016).

Irawan, Andrie. "Jaminan Hak Politik Perempuan Dalam Islam.” Jurnal Ulumuddin 4, no. 2 (2014): 80-87.

Mahmud, Amir. "Pesantren dan Pergerakan Islam, Studi Tentang Alumni Pondok Pesantren al-Mukmin, Ngruki, Surakarta.” UIN Sunan Kalijaga, 2008.

Musaropah, Umi. "Pemberdayaan Masyarakat Dalam Penyelenggaraan Pendidikan Anak Usia Dini Berbasis Pesantren.” aș-șibyan, Jurnal Pendidikan Guru Raudlatul Athfal, Vol.1, No.2, Tahun 2016, h. 177-185, http://jurnal.uinbanten.ac.id/index.php/assibyan/ article/ view/203

Nugroho, Taufik. “Analisis Manajemen Pendidikan Terhadap Kualitas

${ }^{16}$ Azyumardi Azra, Esei-esei Intelektual Muslim dan Pendidikan Islam (Jakarta: logos Wacana Ilmu, 1998), h. 124. 
Madrasah Indonesia." Jurnal Ulumuddin 6, no. 2 (2016): 80-87.

- - . "Pendidikan Karakter Dalam Al-Qur'an (Studi Tafsir Pendidikan Surat Luqman)." Jurnal Ulumuddin 4, no. 1 (2014): 14-22.

Steenbrink, Karel A. Pesantren, Madrasah, Sekolah. Jakarta: LP3ES, 1986. 